\title{
O fascínio da imagem: a experiência do fora e o filme $O$ estranho caso de Angélica
}

Maicon Barbosa

\section{Resumo}

Este ensaio pretende pensar um modo de relação com as imagens que acontece como experiência de fascínio, a partir de alguns fragmentos da obra de Maurice Blanchot e do filme $O$ estranho caso de Angélica, do diretor português Manoel de Oliveira. Por meio de uma escrita das imagens do filme, o texto se propõe a pensar o fascínio - concepção instável que aparece em diferentes textos de Blanchot sobre a experiência literária - como uma relaçáo com o fora, que arrasta o pensamento para uma regiáo desconhecida, para o acaso que não se submete à primazia de uma interioridade reflexiva. Trata-se de apostar no fascínio da imagem como abertura às forças inomináveis e inquietantes que estremecem subjetividades ensimesmadas e que levam o pensamento a confrontar seus limites.

Palavras-chave: fascínio; imagem; cinema; Maurice Blanchot; Manoel de Oliveira.

\section{Résumé}

Cet essai vise à penser un mode de relation avec les images qui se produit comme une expérience de fascination, à partir de quelques fragments de l'œuvre de Maurice Blanchot et du film L'étrange affaire Angélica, réalisé par le cinéaste portugais Manoel de Oliveira. Au moyen d'une écriture des images du film, le texte propose de penser la fascination - une conception instable qui apparait dans différents écrits de Blanchot sur l'expérience littéraire - comme une relation avec le dehors, qui entraîne la pensée dans une région inconnue, vers le hasard qui n'est pas soumis à la primauté d'un intérieur réfléchissant. Il s'agit de miser sur la fascination de l'image comme ouverture aux forces anonymes et inquiétantes qui font trembler les subjectivités fermées sur elles-mêmes et qui mènent la pensée à affronter ses limites.

Mots-clés: fascination; image; cinéma; Maurice Blanchot; Manoel de Oliveira. 
plural, 2010a; Idem. A conversa infinita II: a experiência limite, 2007; Idem. A conversa infinita

III: a ausência de livro, o neutro, o fragmentário, 2010b.

2. FOUCAULT, Michel. "O pensamento do exterior", 2009.
Algumas imagens fascinam. Atraem irresistivelmente quem olha, absorve por um tempo o corpo daqueles que as encontram. Vistas a olho nu e imaginadas, avistadas também de olhos fechados, nos sonhos, olhadas inclusive por aqueles que perderam ou nunca tiveram a visão dos olhos, essas imagens corrompem por meio de uma sedução, aliciam os gestos do olhar, deixando-os suscetíveis a forças diversas que vagueiam nas superfícies imagéticas e nos espaços vazios que entremeiam as próprias imagens. Mas, de onde viria essa experiência de fascínio diante da imagem? Fascinado, o olhar é tragado pela imagem, atraído por ela com uma força deslumbrante que o faz soçobrar em sua superfície fendida. Como um buraco no meio de um oceano, um redemoinho que assusta e convida, a imagem fascinante abre um turbilhão, vai engolindo o mundo daquele que olha $\mathrm{e}$ imagina. Por um tempo que dura para além das mediçôes dos ponteiros e dos calendários, o mundo inteiro se transforma naquela imagem, atraente e avassaladora. Aquele que olha essa imagem, que se deixa mergulhar nela, abre máo temporariamente, mesmo que sem saber, da capacidade de decidir e de escolher diante da imagem.

Em diferentes textos que interpelam a criação na experiência literária, Maurice Blanchot nos fala do fascínio da imagem, quase sempre de maneira instável, como uma relação com o fora, que atrai o pensamento para um espaço desconhecido e imaginário que não se submete à primazia da interioridade reflexiva. O fascínio como conceito oscilante, que aparece em textos distintos escritos por Blanchot, associa-se inevitavelmente à imagem, a sua distância atraente, remete-nos a um encontro assombroso com uma ausência que se torna presente. Além de aparecer em alguns dos escritos de Blanchot considerados como textos de crítica literária, a experiência do fascínio já estava presente, de algum modo, em suas primeiras ficçóes. Entretanto, crítica e ficção em Blanchot são modos de escrita e de pensamento que não cessam de se atravessar, como em $A$ conversa infinita ${ }^{1}$, que se constitui por diálogos variantes entre duas vozes que percorrem questóes filosóficas e literárias, levando a escrita a um limiar de indiscernibilidade, fazendo-a abrir-se para uma diferença que não se sintetiza e que recusa trancafiar o estilo em uma única forma. Para Michel Foucault ${ }^{2}$, as ficçôes em Blanchot situam-se no interstício das imagens, no espaço entre elas que as entrelaça, e colocam-se não nas formas sólidas das figuras, em seus contornos demasiado duros, mas sim, nos deslocamentos e nas transfiguraçôes que as arrebatam irremediavelmente. Entretanto, essas ficçôes são precisas, e desenham suas imagens na monotonia do cotidiano, na insistência do 
anônimo que reverbera o fora, na recusa à marca indelével de um nome que remeteria à interioridade. Essa escrita ficcional não estaria nem nos humanos nem nas coisas, e sim, naquilo que está entre eles, no vácuo que introduz uma distância entre esses corpos. A força do encantamento nessas ficçóes, a experiência atordoante do fascínio emerge justamente nos espaços vazios, nos abismos que se colocam entre as imagens, que as ligam e as separam ao mesmo tempo.

As ficçôes em Blanchot serão, mais do que imagens, a transformação, o deslocamento, o intermediário neutro, o interstício das imagens. Elas são precisas, e só têm figuras desenhadas na monotonia do cotidiano e do anonimato; e quando dáo lugar ao encantamento, não é jamais nelas próprias, mas no vazio que as circunda, no espaço onde são colocadas sem raiz e sem fundaçóes. ${ }^{3}$

Ainda em $O$ pensamento do exterior, Foucault assinala que a escrita de Blanchot acontece por uma atração, noção que também se liga ao conceito de fora. A atração marca a presença do fora em Blanchot e nos coloca na condiçáo de exterioridade em relaçáo a esse fora. Dito de outro modo, é pela atraçáo que se experimenta a presença do fora, mas, simultaneamente a esse contato, experimenta-se também a condição de estar fora do próprio fora.

Em outro texto, Foucault ${ }^{4}$ nos diz que Blanchot abriu uma zona de perturbação na crítica literária em suas escritas, que não se dispunham a interpretar uma obra, um livro ou um texto, tentando desvelar sua interioridade verdadeira. A partir de um texto, Blanchot engendra outras escritas que tomam direçôes inesperadas, sem se submeter à ilusória exigência de decifração da obra. A crítica que emerge com Blanchot não busca encontrar a verdade escondida da obra, náo intenta desvelar o segredo, o sentido encoberto que supostamente existiria num texto. Ela cria outras relações de pensamento a partir da obra interpelada, e não mais se preocupa em encontrar uma verdade original escondida. O que desponta é a possibilidade de produzir escritas a partir dos elementos fornecidos pela obra, pela materialidade do texto. Mas, não se trata de uma análise formalista que se concentra apenas na forma do texto em si, pois urge levar em consideração outras forças que criam condições para o aparecimento da obra e que desdobram seus efeitos de modo imprevisível. Neste ensaio, inspirados nessa crítica desdobrada por Blanchot, pretendemos escrever com o filme $O$ estranho caso de Angélica, e fazer as imagens retinirem no texto sem uma intenção de resolução interpretativa ou de uma simples descrição que imita a imagem cinematográfica na escrita. No primeiro momento do ensaio criaremos uma escrita das imagens em movimento do filme, e pensaremos uma coexistência temporal entre passa-
3. Ibidem, p. 225.

4. Idem. "Sobre as maneiras de escrever a história", 2008. 
5. OLIVEIRA, Manoel de.

O estranho caso de Angélica, 2010. do e presente na montagem dessa obra de Manoel de Oliveira. No segundo momento, a partir de alguns fragmentos da obra de Blanchot, pensaremos a experiência do fascínio da imagem como uma abertura incessante ao fora.

\section{O rosto do fascínio ou 0 estranho caso de Angélica ${ }^{5}$}

Uma chuva fraca caía sem pressa acariciando as pequenas pedras retangulares que se enfileiravam ao longo da rua, formando um calçamento com aspecto de tempos idos. $\mathrm{Na}$ penumbra da madrugada que ia ficando cada vez mais funda, uma rua sinuosa se deixava ver, clareada parcamente pelas luzes dos postes e pelos faróis de um carro que estaciona em frente a uma loja de fotografia. O homem que sai do carro, no meio da água fina que molha lentamente o guarda-chuva, procura o fotógrafo que mora naquela casa. Como o velho retratista havia viajado para a cidade do Porto, era preciso encontrar alguém que pudesse, naquela hora da madrugada, tirar algumas fotografias. Um transeunte que por ali passava falou de um forasteiro, que estava na cidade há não muito tempo e que andava a tirar fotografias por todos os lados. Isso interessou ao homem que procurava com urgência um fotógrafo e logo os dois seguiram pela noite rumo ao forasteiro.

Num quarto de pensão, sentado a uma pequena mesa, Isaac tentava sem êxito consertar um ruidoso rádio. As paredes acinzentadas do quarto pareciam absorver a pouca luminosidade expelida, sobretudo, por uma luminária de mesa. A fumaça de cigarros subia lentamente passando por um fio estendido de uma ponta a outra do quarto, onde se podia ver penduradas algumas fotografias recém-reveladas. Atrás da mesa em que o rádio aberto fazia barulhos demorados, a chuva silenciosa escorria pelos vidros da janela da varanda, que dava para a rua. Dali podia-se ver logo do outro lado da alameda o gordo rio que banhava, delongado, as margens da pequena cidade. Mas, a uma hora daquelas, o que se via de dentro do quarto eram pequeninas luzes bruxuleantes que atravessavam, meio deformadas, a cortina de água que descia pelo vidro da janela. Misturando-se aos ralos traços de fumaça que serpenteavam pelo quarto, algumas palavras saltaram da boca de Isaac, cujos olhos lassos olhavam para um lugar desconhecido.

Dançai!, ó estrelas, que seguis constantes

Vertigens matemáticas fixadas!

Delirai, e fugi por uns instantes 
À trajectória a que ides algemadas!

Tempo! detém-te! E vós, criaçôes de dantes,

Que errais por celestiais, irreais estradas,

Anjos! abri-me os pórticos dos céus,

Que em minha noite é dia...

Antes que as palavras pudessem precipitar-se no silêncio, alguém bateu à porta apressadamente: era a dona da pensão que entrou afoita no quarto assim que a porta se abriu. Ela dizia que o estavam procurando para que fosse tirar fotografias àquela hora, em um lugar chamado Quinta das Portas. Depois de umas poucas indagaçôes à dona da pensão, Isaac vestiu-se e pegou a antiga câmera fotográfica; atravessando a rua em frente à hospedaria, meteu-se no carro que o esperava debaixo da persistente chuva.

O rosto de Angélica era de uma palidez incomum. Descorado como se já não houvesse mais sangue pulsando em baixo da pele brancamente delicada. Ao redor, alguns vultos negros permaneciam sentados em cadeiras dispostas num semicírculo. Uma comoção pesarosa marcava os rostos silenciosos que permaneciam quase imóveis diante daquela face pálida, que arrastava os olhares como um imã atrai alfinetes. $O$ vestido branco contrastava delicadamente com o azul escuro do tecido que cobria a superfície do antigo divã, onde seu corpo permanecia imóvel. No meio da sala, como se tivesse sido colocado ali para isso, um lustre sóbrio concentrava seu fulgor sobre o vestido e o rosto adormecido, fazendo com que a brancura de ambos jorrasse sem exageros pelo aposento. Com olhos tardos, alguns miravam inconsolados aquele rosto inerte; cabisbaixos, outros lançavam o olhar para o cháo ou para um longe lugar.

Um tanto quanto desajeitado, Isaac se pôs em frente ao corpo que repousava tranquilamente no divã, empunhou a câmera e encaixou seu olho direito no buraco da máquina. Entretanto, a lâmpada que iluminava a sala era fraca, e foi preciso trocá-la por outra de maior claridade. Enquanto buscavam a outra lâmpada, Isaac sentou-se junto aos que por ali estavam, e por entre os cochichos de duas senhoras, olhou meio admirado para a jovem mulher que estava deitada no meio da sala. O lugar entrou numa ligeira penumbra no momento em que o fotógrafo trocava a lâmpada. A luz mais forte ressaltou ainda mais as curvas frágeis daquele semblante pálido. Isaac tomou nas mãos, outra vez, a câmera que prendia-se a seu pescoço por uma estreita correia de couro, e procurou a melhor posição para focar o rosto de Angélica. Agachou-se para alcançar um ângulo melhor; levantou-se e se moveu para o lado direito. Guardou no bolso da calça o lenço que lhe fora entregue pela governanta, com o qual havia feito a substituição da lâmpada. Agachou-se de novo e ergueu-se mais uma vez. Aproximou-se mais da mulher deitada sobre o divã. Enfiou o olho no visor da máquina nova-
6. RÉGIO, José. "Sarça

Ardente", 1970 
mente. Regulou um pouco mais a objetiva com a mão esquerda, mas, quando conseguiu ajustar o foco, algo estranho o fez recuar diante da imagem: por um momento incapturável ele viu o rosto de Angélica desabrochar em um sorriso. Assustado, Isaac baixou a câmera, afastou-se para trás e olhou atônito para o cadáver e para as pessoas que por ali faziam velório. A jovem mulher morta permanecia imóvel; o que se notava era a mesma aparência, discretamente risonha, de antes. Atormentado, o fotógrafo não mais conseguia se concentrar, olhava para os lados como se estivesse procurando a presença de alguém. Sua inquietude fez com que a irmã da falecida viesse perguntá-lo, com um tom de reprovação, se as fotografias já haviam sido tiradas.

Sobressaltado e ao mesmo tempo atraído cada vez mais pela imagem do rosto falecido, Isaac começou a capturar a imagem inquietante daquela mulher que parecia dormir um sono sereno. O pavor que havia tomado o seu corpo trouxe um certo incômodo a alguns daqueles que pacientemente passavam a noite na vigília. Sem demora o fotógrafo fez quatro fotos da falecida, cada uma de um ângulo diferente, e logo arrancou a câmera do pescoço, desembestado. Colocou a máquina na sua bolsa de couro, e num pulo dirigiu-se para a porta. Antes de cruzar o umbral, olhou para Angélica e fez um aceno curto com a cabeça para aqueles que permaneciam sentados. Saiu da sala apressado, sem dizer palavra alguma, mas o som ruidoso dos seus passos - que nascia no encontro dos sapatos com o velho assoalho de madeira - ecoavam por toda a grande casa.

De volta ao quarto de pensão, na manhã seguinte, o fotógrafo revelava diligentemente as fotos tiradas no velório. Um retrato de dois burros arrastando um arado fora removido do varal que cruzava o cômodo, e uma a uma, as fotografias feitas durante a noite iam sendo dependuradas no cordáo. Depois de ter colocado todos os retratos no varal, Isaac as mirou por um tempo, e mais uma vez, a imagem parecia se mover, apavorando-o. Após ter olhado a perturbadora imagem de Angélica, o mundo de Isaac naufragou naquele rosto pálido, meio risonho, que saltou do leito de morte para a lente da máquina fotográfica. A imagem da morta inundou os olhos e a imaginação do fotógrafo, levando-o às regiōes insólitas do fascínio. Seus sonhos, quase sempre intranquilos, passaram a ser povoados pela insistente imagem da falecida. Na noite seguinte ao velório, ele acordou de súbito, ofegante, gritando o nome de Angélica, depois de ter sonhado com ela num passeio noturno. Um estranho encantamento o atraía: essa imagem fascinou Isaac de tal forma que ele a via por toda parte. Depois do encontro com as potências estranhas do semblante dessa mulher finada, o fotógrafo saiu de si, atraído pelas forças inomináveis dessa imagem, como no poema - que ele mesmo havia declamado solitariamente antes de sair de casa 
no meio da madrugada - em que o poeta desejava que as estrelas delirassem e saíssem da trajetória à qual iam algemadas.

Outras imagens também interessavam a esse fotógrafo de poucas palavras; tratava-se das imagens daquilo que estava desaparecendo, sobretudo do trabalho à moda antiga - como ele mesmo o chamava - dos homens que revolvem a terra nas plantaçôes usando instrumentos de outros tempos. Obstinado, Isaac se punha a fazer fotografias desses lavradores, que trabalhavam em uma vinha localizada do outro lado do rio, em um terreno bastante íngreme. Enquanto aqueles homens feriam a terra pedregosa com furiosas enxadadas, cantavam juntos uma cançáo de tempos idos. Ao passo que os lavradores faziam subir uma poeira do chão com os fortes golpes de enxada, o fotógrafo capturava as imagens, por entre pequenas estacas fincadas no solo, que estendiam muitos fios de arame. Andando rápido pelo terreno acidentado, Isaac procurava as imagens, mudava de posição para que elas pudessem aparecer ao seu olho inquieto. Ele procurava imagens que quase não se via mais naquele lugar. Poucos na vila se interessavam por aquela labuta braçal: a dona da pensão, intrometida que era, interrogava Isaac sobre o estranho interesse por um trabalho que estava quase desaparecido por ali, dizendo que agora tudo se fazia de outra forma, com máquinas. Mas, o fotógrafo retrucava, falando que era justamente as coisas à moda antiga que o interessavam.

Em outra noite, ele acordou apavorado de um pesadelo em que se ouvia o som das enxadas a golpear a terra. Sentou-se na cama, acendeu a luminária do criado-mudo, e tentou recuperar o ar que parecia não chegar aos pulmóes. Meio moribundo, levantou-se e foi ter com as fotos penduradas no varal. Seu olhar passeava pelos retratos presos ao fio: as fotos de homens empunhando enxadas, esfolando o chão com antigos instrumentos de ferro, se intercalavam com as imagens da jovem mulher fenecida. Depois de passar o olho por toda a extensão do barbante, parou em frete à imagem de Angélica. Olhou para ela encantado, e no tempo impreciso desse olhar enfeitiçado, virou-se para trás bruscamente algumas vezes, procurando pela presença de alguém. Isaac desejava as imagens que estavam desaparecendo do mundo. De algum modo, queria fazê-las sobreviver ao aniquilamento.

Sentados à mesa, de uma maneira não habitual, os outros hóspedes olhavam pacientemente a dona da pensão, que ao pé da gaiola pendurada na parede lateral do aposento lamentava profundamente a morte do seu passarinho. Como de costume, esses hóspedes - uma mulher ainda jovem e dois homens marcados pelo curso dos anos - tomavam o café da manhã e bisbilhotavam a vida do solitário fotógrafo, trocando fuxicos com a dona da pensão. Comentavam sobre os curiosos barulhos que vinham do quarto do moço retratista, ao longo da noite. Justo naquele instante, Isaac entrou pela porta e todos logo trataram de engolir 
7. 'J'ai adapté le projet aux circonstances de l'époque. Le projet a été créé après la Deuxième Guerre Mondiale [...] Mais la guerre a eu lieu il y a longtemps, au siècle dernier, de même que les vignes du Douro sont différentes, les ponts et les maisons sont autres. Certaines choses se maintiennent alors que d'autres ont changé" (OLIVEIRA, Manoel de. La Métaphysique des anges: entretien avec Antonio Preto, 2010, p. 04, tradução livre). o falatório. Ele olhou o passarinho caído, e ao ouvir que o pintassilgo havia morrido, saiu correndo desembestado. Seus passos ganharam a rua e corriam com desespero pela vila. $\mathrm{Na}$ corrida desenfreada, chocou-se contra uma mulher numa calçada; passou por uma fonte de onde brotava uma água tranquila; dobrou esquinas; cruzou uma praça indo na direção oposta àquela indicada por uma estátua resignada; parou por um segundo na porta do cemitério, gritou o nome da mulher falecida e voltou a correr; subiu uma ruela encravada numa ladeira tortuosa onde duas senhoras o olhavam com surpresa... O fotógrafo corria não se sabe para onde. Corria em busca da imagem que o fascinava tanto, do semblante desaparecido, aparentemente inerte e risonho, que continuava presente nas fotografias e na imaginação? Essa corrida desesperada, que tanto o fazia ofegar, o arrastaria ao próprio espaço sem fundo de onde a imagem jorrava: correria torpe que o levaria ao encontro de uma desconhecida morte.

$*$

A história da criação desse filme português, concebido e dirigido por Manoel de Oliveira é bastante incomum. O primeiro roteiro havia sido escrito entre os anos de 1952 e 1954 pelo diretor, mas naquele tempo não foi possível realizar o filme. O próprio Manoel de Oliveira nos diz que escreveu a primeira versão do roteiro pouco tempo depois da Segunda Guerra Mundial, e que a perseguição nazista aos judeus na Europa foi determinante para a criação do protagonista Isaac, que é um fotógrafo judeu. Mas, os caminhos que Isaac tomaria se o filme tivesse sido feito no pós-guerra teriam sido diferentes, certamente. Em uma entrevista, quando perguntado se a obra era uma adaptaçáo de si mesmo, do roteiro escrito nos anos cinquenta, o cineasta nos diz:

Adaptei o projeto às circunstâncias da época. O projeto foi criado depois da Segunda Guerra Mundial [...] Mas a guerra aconteceu há muito tempo, no século passado, da mesma forma que as vinhas do Douro estáo diferentes, as pontes e as casas são outras. Certas coisas se mantiveram enquanto outras mudaram. ${ }^{7}$

Escrito no início dos anos cinquenta, o filme esperou mais de meio século para ser filmado. É como se a própria história do filme, o roteiro e a imagem insistente de um fotógrafo que se torna fascinado pelo rosto de uma morta, retornassem do sono do mundo. Régua, no vale do Douro, ao norte de Portugal, é a 
cidade do filme. As ruas e arredores de Régua são indissociáveis da montagem das imagens, como na primeira versão escrita há mais de cinquenta anos. Mas, por que o filme não foi rodado na época? Algo determinante para que a película não fosse filmada nos anos cinquenta foi a censura da ditadura de Salazar ${ }^{8}$. A decupagem completa do filme - que incluía inclusive a duração dos planos - escrita na época foi submetida à Secretaria Nacional de Informação, órgão responsável pela censura. No entanto, nenhuma resposta foi dada ao cineasta, como se ele nunca tivesse enviado coisa alguma para esse lugar'. Mas, a censura silenciosa não destruiu o filme, que persistentemente faria sua aparição muito tempo depois.

Esse atraso, que distancia a escrita da primeira versão e a feitura do filme, insere diferentes farpas de tempo nas imagens. $\mathrm{O}$ passado dos anos cinquenta retorna em certos gestos e objetos: na ausência de televisão, de aparelhos celulares ou computadores; nos velhos livros do fotógrafo; na sua antiga câmera analógica; no seu modo de se vestir; no trabalho à moda antiga dos lavradores... Mas, ao mesmo tempo o filme não cessa de mostrar uma cidade contemporânea com seus atuais edifícios e carros. A coexistência de tempos divergentes nas imagens torna presente a própria força de sobrevivência desse filme, que esperou o decurso dos anos para finalmente aparecer no ecrá.

Apesar de privilegiarmos a imagem nesse ensaio, não se trata de acreditar em uma imagem pura, isolada dos outros elementos que compóe o filme, como os sons, a música e os diálogos. Em relação à sua atual visão do cinema, Manoel de Oliveira aproxima essa arte de uma construção arquitetônica composta por quatro colunas que sustentam um pórtico, como nos templos gregos. "A primeira coluna seria a da imagem, a segunda, a da palavra, a terceira, a do som, e a quarta, a da música; o pórtico frontal que sustentam representaria a ideia geradora que lhes dá sentido e unidade" ${ }^{10}$.

A presença intensa do som remete a uma agonística temporal entre passado e presente no filme: o barulho das velhas ferramentas de trabalho dos lavradores atravessa o filme, junto com um canto arcaico que esses homens entoam enquanto golpeia a terra, nas vinhas às margens do Douro. Mas, o som das máquinas atuais também perpassa o filme, como o barulho ensurdecedor dos caminhóes que invadem o quarto de Isaac mais de uma vez. Os antigos sons do trabalho manual nas vinhas, que está desaparecendo - como diz a dona da pensão em um dos diálogos com Isaac - entrecortam-se por sons das máquinas contemporâneas, como carros, caminhôes e tratores.

A música do filme é constituída unicamente por composiçôes de Frédéric Chopin, com extratos da Sonata n $3 \mathrm{em}$ si menor op. 58, e das Mazurkas op. 59. O piano é o único instru-
8. BEGHIN, Cyril. Manoel de Oliveira: L'étrange affaire Angélica, 2013, p. 03.

9. OLIVEIRA, Manoel de. Angélica (1954): un découpage, 1993 , p. 06.

10. Idem. "Esta minha paixão", 2005, p. 172-173. 
11. OLIVEIRA, Manuel de.

O estranbo caso de Angélica, 2010.

12. WARBURG, Aby. "Dürer e a antiguidade Italiana", 2013a; Idem. "A emergência do estilo ideal à antiga na pintura do início do Renascimento", 2013b.

13. Em seu trabalho sobre o pensamento de Aby Warburg, Georges Didi-Huberman nos fala dos efeitos atordoantes da obra inclassificável do pensar alemão para a história da arte. Cf. DIDI-HUBERMAN, Georges. A imagem sobrevivente: história da arte e tempo dos fantasmas segundo Aby Warburg, 2013.

14. O patético deriva de pathos, e aparece para mostrar uma carga afetiva das imagens, aquilo que move e comove pela intensidade dos afetos. mento que se ouve nas músicas do filme, o que produz um minimalismo da atmosfera musical, em que a repetição das melodias e harmonias de Chopin se associa à reaparição das imagens e dos sons do passado no presente. O reaparecimento dos enigmáticos acordes de piano intensifica o retorno das imagens de Angélica, das imagens dos lavradores, dos sons de outrora atravessados pelos barulhos de uma cidade de agora.

Em muitos diálogos do filme a tensão temporal entre passado e presente também aparece, como na conversa entre os outros hóspedes e a dona da pensão, que falam, abismados, sobre a estranha obstinação do fotógrafo em relação às coisas que estáo a desaparecer. Matias, um dos hóspedes, cita o filósofo espanhol José Ortega y Gasset, quando fala do "homem e sua circunstância”, referindo-se ao desconhecimento sobre o passado do fotógrafo. Instantes depois, no mesmo diálogo, o engenheiro, que também está hospedado na pensão, fala da atual crise econômica em Portugal que impediu a construção de uma nova e longa ponte sobre o rio Tejo. Uma das falas de Justina, a dona da pensão, mostra de maneira incisiva a presença dessa coexistência conflituosa entre passado e presente nesse filme cujo primeiro roteiro foi escrito ainda nos anos cinquenta.

Tanto lhe disse para não perder tempo a tirar fotos àquela gente! [...] Porque são pouquíssimas essas vinhas à moda antiga. Agora é tudo à máquina! Mas, ele [Isaac] não me deu ouvidos. Sabe o quê que ele me disse? "Pois é isso à moda antiga que me interessa!" E foi-se. Fiquei sem saber o que é que o atrai. ${ }^{11}$

Em O estranho caso de Angélica é possível notar a presença da Ninfa, imagem da Antiguidade que reaparece em muitos outros momentos de diferentes formas, em materialidades imagéticas distintas. O pensador alemão Aby Warburg ${ }^{12}$ - cuja obra inominável estremeceu a História da $\operatorname{arte}^{13}$ na passagem do século xix para o século xx - analisou os reaparecimentos da Ninfa a partir do conceito de sobrevivência - Nachleben -, mostrando as ligaçóes entre a Antiguidade pagá e o Renascimento. A sobrevivência refere-se às reapariçóes de forças patéticas ${ }^{14}$ do mundo antigo, de imagens e gestos artísticos de outrora, que retornaram de inúmeras formas na estética renascentista: em pinturas, esculturas, desenhos, xilogravuras, gravuras em metal, detalhes arquitetônicos, entre outros modos de feitura material das imagens naquele momento. Nas análises de Warburg sobre o retorno de traços da Antiguidade em obras de arte do Renascimento, a imagem da Ninfa carrega uma potência de movimento quando retorna de tempos idos ao mundo renascentista cristianizado: essas imagens pagãs, que viriam de lugares e tempos diversos, se reuniram em diferentes formas de arte. 
[...] durante minha estada em Florença, percebi que a influência da Antiguidade na pintura secular do Quattrocento - especialmente em Botticelli e Filippino Lippi - manifestou-se numa remodelagem da aparência humana por meio de um movimento acentuado do corpo e da vestimenta segundo os modelos fornecidos pelas artes plásticas e poéticas da Antiguidade. Mais tarde, vim a reconhecer que os superlativos autenticamente antigos da linguagem gestual também estilizaram a retórica gestual de Pollaiuolo e, sobretudo, que até mesmo o mundo fabuloso do jovem Dürer (de $A$ morte de Orfeu a $O$ grande ciúme) deve o impacto dramático de sua expressão a essas 'fórmulas de $p a ́$ thos' sobreviventes e autenticamente gregas, que lhe haviam sido transmitidas pela Itália setentrional. ${ }^{15}$

Com a sobrevivência de traços e forças da Antiguidade, por meio da reaparição das imagens patéticas do mundo antigo, os artistas plásticos do Renascimento se viram diante de um problema que retornaria em muitos outros momentos: como mostrar na imagem a vida em movimento? "No século xv, a 'Antiguidade' não exige dos artistas que prescindam das formas de expressão conquistadas pela observação própria [...], antes volta a atençáo para o problema mais difícil das artes plásticas, a representação da vida em movimento" ${ }^{16}$. Essa sobrevivência de antigas forças e formas, que atravessam os abismos tentadores do esquecimento e reaparecem na arte renascentista, fazem com que as imagens estáticas ganhem traços de movimento. Em muitas imagens analisadas por Warburg, sobretudo, nas obras de Sandro Botticelli $O$ nascimento da Vênus e A Primavera, o movimento se faz ver nas roupas sopradas pelos ventos, no balanço dos cabelos e dos acessórios, e nas danças dionisíacas que envolvem os corpos das antigas Ninfas pagás que voltam ao Renascimento. "[...] a partir do momento em que Botticelli se familiariza com as ninfas da Antiguidade, na arte e na poesia, a figura da mulher em movimento adquire aquela beleza vibrante e autoconsciente com a qual se manifesta pela primeira vez no afresco de Sandro na Capela Sistina [...]"17 Georges Didi-Huberman ${ }^{18}$ nos diz que Warburg elaborou o conceito de Pathosformel - fórmulas patéticas das imagens que sobrevivem -, sobretudo, para pensar a presença constante dos movimentos na pintura renascentista, $\mathrm{e}$ nesse sentido, a figura da Ninfa em suas múltiplas possibilidades de aparição mostra a intensidade do conceito de Pathosformel. "A Ninfa, portanto, é a heroína do encontro movente/comovente [...] A Ninfa se encarna, ou seja, é tanto mulher quanto deusa: Vênus terrestre e Vênus celeste, dançarina e Diana, serva e Vitória, Judite castradora e Anjo Feminino [...]"19

No filme de Manoel de Oliveira, a personagem Angélica nos remete ao imaginário do mundo dos anjos, que no ocidente passa inevitavelmente pelo imaginário judaico-cristão. Entretan-
15. WARBURG, Aby. "A arte Italiana e a astrologia internacional no Palazzo Schifanoia, em Ferrara", 2013c, p. 453.

16. Idem. "O nascimento da Venus e A Primavera de Sandro Botticelli”, 2013d, p. 53.

17. Idem. "Sandro Botticelli", 2013e, p. 91.

18. DIDI-HUBERMAN, $A$ imagem sobrevivente: história da arte e tempo dos fantasmas segundo Aby Warburg, 2013

19. Ibidem, p. 220. 
20. AGAMBEN, Giorgio.

Ninfas. 2012, p. 29. to, nos interessa pensar os traços da imagem do anjo feminino que aparecem no filme como uma reaparição da figura da Ninfa, considerando os trabalhos de Warburg que analisam o reaparecimento das Ninfas pagãs nas artes plásticas angelicais e sacras do Renascimento. No passeio noturno com Isaac, enquanto deslizam sobre o rio Douro, os cabelos de Angélica entram em movimento, soprados pelo vento, assim como seu branco vestido drapeado que se move incessantemente em meio à escuridáo. Em outra cena, Angélica aparece no quarto de Isaac, rente ao teto, e mais uma vez um forte vento agita seu vestido e seus cabelos. Em $O$ estranho caso de Angélica há uma presença dessa relação entre a figura da Ninfa e o movimento: essa velha imagem da Ninfa sobrevive, insiste no tempo mesmo diante das subsequentes destruiçóes cotidianas, reaparece transformada no filme, carregando traços da imagem de anjo. Entretanto, não se trata de dizer que há nesse filme uma simples repetição da Ninfa pagã na forma de anjo feminino, como se estivéssemos diante de uma imagem arquetípica que reaparece exatamente da mesma forma em momentos diferentes. Esse retorno da imagem da Ninfa implica uma espécie de desfiguração daquilo que reaparece, uma transformação que mostra as marcas do próprio processo de desaparecimento. Como nos diz Agamben, "[...] a ninfa não é uma matéria passional à qual o artista deve dar nova forma, nem um molde ao qual deve submeter seus materiais emotivos. A ninfa é um composto indiscernível de originalidade e repetição, forma e matéria" ${ }^{20}$.

\section{O fascínio e o fora}

$\mathrm{Na}$ experiência do fascínio algo se passa como se a imagem decidisse em nós, como se ela nos escolhesse, nos fazendo chafurdar nesse espaço longínquo de onde ela emana e desaparece. Entrar no fascínio: embrenhar-se no espaço próprio às imagens e pisar desavisado no chão vago e desconhecido que é a distância da imagem, o seu quase feitiço. Algumas imagens carregam a força de nos arrebatar; elas podem nos despojar de nós mesmos, fazendo-nos sair do demasiado conforto asfixiante de uma interioridade fechada sobre si, que busca isolar-se daquilo que não é familiar e reconhecível. Encontrar essas imagens é entrar em relaçáo com o fascínio, com o canto das sereias que nos arrasta para fora de nós, que nos impele para direçôes insuspeitadas e turvas, desmantelando a clausura de uma subjetividade calcada na interioridade. Olhar a imagem, mesmo que seja imaginariamente, pode nos colocar na presença daquilo que é inesgotável; essa imagem faz passar uma fascinação que nos arranca dos luga- 
res conhecidos, lançando-nos em uma experiência indeterminada - que já não se define apenas por aquilo que é possivel -, sem as referências que decidiriam os rumos por vir.

O que nos é dado por um contato a distância é a imagem, e o fascínio é a paixão da imagem. [...] O fascínio é o olhar da solidão, o olhar do incessante e do interminável, em que a cegueira ainda é visão, visão que já não é possibilidade de ver mas impossibilidade de não ver, a impossibilidade que se faz ver, que persevera - sempre e sempre - numa visão que não finda: o olhar morto, olhar convertido no fantasma de uma visão eterna. ${ }^{21}$

Nessa experiência radical do fascínio torna-se impossível não ver, não imaginar; a imagem transforma-se em um labirinto, que amedronta e atiça, diante do qual o ato de olhar não é mais uma questão de possibilidade. O fascínio, entáo, se faz em uma relação com a impossibilidade; experiência que não é simplesmente uma decisão daquele que está perante a imagem. O fascínio arruína a possibilidade de escolher, desmantela os hábitos arraigados na aparente soberania de uma escolha intencional e segura de si mesma. Aquele que está entregue ao fascínio sente na pele a estranheza do impossível, dessa impossibilidade que se refere a um desencontro com o verbo poder: a fascinação nos empurra para uma estranha relação com o impossível, em uma experiência que não passa pelo poder de escolha. Essa abertura para o impossível que acontece ao fascinado não se coloca como algo irreal, como se estivesse em oposição a uma realidade que seria possível: o impossível não nos conduz ao inexistente. A impossibilidade presente no fascínio aparece como algo que destoa dos gestos constituídos a partir do poder de ou do poder para: trata-se de um abandono do poder como verbo transitivo direto, que pressupóe a existência de um sujeito da ação que tem a faculdade consciente para fazer, decidir e escolher alguma coisa.

Mas, dizer que no fascínio não se pode escolher não significa que essa experiência é algo meramente espontâneo, como se se tratasse de uma espécie de predestinação: entrar no fascínio é ser tomado, no presente, por forças da imagem, do mundo e da própria história que constitui aquele que olha e imagina. No instante em que a imagem se encontra com o olhar e com a imaginação, forças do fora que retornam do sono do mundo saltam na superfície do presente e constituem a fascinação. Nas imagens fascinantes, farpas de outros tempos voltam ao presente, $\mathrm{e}$ desdobram uma experiência afetiva arrebatadora. A fascinação nasce de um confronto com o mundo e desdobra contágios por meio dos fragmentos de tempo que saltam no encontro com o presente. Como nos diz Georges Didi-Huberman, partindo dos escritos de Blanchot que transpassam a questão da imagem na experiência literária, “[...] estar fascinado não é estar enganado: 
22. DIDI-HUBERMAN,

Georges. "De semelhança a semelhança", 2011, p. 29.

23. BLANCHOT, $A$ conversa infinita III: a ausência de livro, o neutro, o fragmentário, 2010b, p. 66.

24. Idem. O espaço literário, 2011. não é submeter-se à aparência enganadora das coisas, mas sofrer verdadeiramente sua aparição que retorna" ${ }^{22}$.

O fascínio da imagem aparece não por uma qualidade essencial que a habita, pois as imagens, sejam elas quais forem, são artefatos, foram fabricadas em algum lugar, e carregam camadas de tempo que foram se sobrepondo. A experiência do fascínio diante de uma imagem nasce pelo encontro com essas camadas de tempo sobrepostas, coexistentes. O fascínio emerge na descontinuidade, nos espaços vazios entre uma imagem e outra, e essa experiência coloca o fotógrafo do filme diante do tremor da imagem, dessa trepidação que nos leva para direçôes insuspeitadas e que toca a espessura assombrosa daquilo que se constitui como o fora de toda imagem. No instante em que fotografa a jovem mulher falecida, Isaac encontra o tremor da imagem, essa oscilação que incessantemente arrebata e que faz a própria imagem sair de si.

A imagem treme, ela é o tremor da imagem, o estremeci-
mento daquilo que oscila e vacila: ela sai constantemente
de si própria, pois não há nada onde ela seja ela própria,
sempre já fora de si e sempre o interior desse exterior, ao
mesmo tempo de uma simplicidade que a torna mais sim-
ples do que qualquer outra linguagem, e sendo na lingua-
gem como que a fonte de onde esta "sai", mas porque essa
fonte é a força mesma de "sair", o jorrar do exterior na
(através da) escrita. ${ }^{23}$

Em um dos capítulos do livro $O$ espaço literário, intitulado As duas versóes do imaginário, Blanchot ${ }^{24}$ nos diz que a imagem se desencontra e se bifurca em dois caminhos possíveis, numa duplicidade que permanece irresolvida. Por um lado a imagem pode colocar-se a serviço da representação da coisa, funcionando como modo de recuperação ideal de algo que já não existe ou que não mais está presente. Esse seria um regime da imagem que tende para a evocação de um objeto, de um acontecimento, a partir de uma relação ambígua que nega e vivifica, ao mesmo tempo, aquilo que está sendo evocado no ato de imaginar. Entretanto, por outro lado, a imagem nos atrai para direçôes divergentes: não se trata mais de evocar algo ausente, pela imagem que se descolou de um objeto qualquer para representá-lo. A segunda versão do imaginário nos coloca diante do próprio abismo agoniado de uma ausência que se afirma como presença insistente, fazendo a imagem se desprender da função de evocação. Essa imagem nasce e se alastra no vácuo de ausência deixado por aquilo que se dissipou na inquietude das forças do mundo. Essa ausência como presença aparece na distância própria às imagens, nos vãos de algo que se passou, nas fendas de um acontecimento que correu para soçobrar alhures. 
Viver um evento em imagem não é desligar-se desse evento, desinteressar-se dele, como queriam a versão estética da imagem e o ideal sereno da arte clássica, mas tampouco é envolver-se nele por uma decisão livre: é deixar-se prender nele, passar da região do real onde nos mantemos a distância das coisas a fim de melhor dispor delas, para essa outra região onde a distância nos detém, essa distância que é então profundidade não viva, indisponível, lonjura inapreciável que se torna como que a potência soberana e derradeira das coisas. ${ }^{25}$

Mas, o que seria essa ausência como presença? A imagem é algo que não está ali ou aqui, diante de nós como uma coisa que supostamente existe por si só no mundo. Essa versão da imagem não seria somente uma presença, como se fosse alguém próximo que ocupa um lugar à mesa, ou que preenche, mesmo que invisivelmente, um espaço qualquer com sua corpulência. A imagem está ausente: ela não está aqui, mesmo quando nos aparece, pois o que a constitui é uma interminável ausência, uma irremediável distância que não é plenamente superada. Mas, essa ausência, essa distância entre nós e uma imagem, é justamente o que nos liga a ela, como se a lonjura própria às imagens fosse a condiçâo de sua constituição e de sua sobrevivência no mundo. O que difere a ausência da imagem de outras ausências é o fato de que essa ausência está insistentemente presente, a imagem torna presente essa ausência, nos coloca frente a esse abismo que nos separa dela.

A imagem, então, torna-se algo como que inalcançável, inacessível, já que não se trata de um objeto que sempre pode ser manipulado apenas pelo uso de uma consciência intencional. Essa imagem, que figura na segunda versão do imaginário, seria então algo transcendente, já que é inacessível? Parece-nos que o transcendente se relaciona com a perenidade das formas, como se elas existissem independentemente das histórias que as forjaram, mas a imagem, apesar de ser, em certa medida, inacessível a um uso intencional contínuo, é sempre forjada, constituída, montada, conspirada, nos encontros e desencontros da existência mundana. Não se trata de um inacessível como algo que paira demasiado alto sobre as cabeças dos mortais. A imagem torna-se inacessível a uma suposta intencionalidade que prevê e prescreve os usos possíveis, que planeja minuciosamente seu futuro. No momento em que a sua lonjura própria, no instante em que a distância entre a imagem e nós é tão intensa que nos arrasta para fora de nós mesmos, ela se torna mais inacessível às formas preconstituídas; mas, é nesse mesmo instante que nos aproximamos do fascínio, dessa experiência avassaladora, desse espaço sem fundo de onde jorram forças inomináveis, que nos puxam para um lugar desconhecido. 
26. BLANCHOT, Maurice.

O livro por vir, 2005.

27. Idem. A conversa infinita III: a ausência de livro, o neutro, o fragmentário, 2010b, p. 66.

28. Idem. O livro por vir, 2005, p. 19.
Escrevendo sobre a obra de Marcel Proust, Blanchot ${ }^{26}$ nos diz que a experiência literária se constitui em um espaço imaginário, em uma zona própria às imagens, onde aquilo que era interioridade torna-se exterioridade. No espaço imaginário da literatura a imagem está para fora, aparece escancarada, sem um lado de dentro. Essa região das imagens, que faz nascer a própria escrita, não se refere a uma simples irrealidade: esse espaço próprio às imagens também é real, inscreve-se carnalmente no corpo de quem entra em relação com ele. Essas imagens do espaço imaginário não são meras evocações de imagens "reais", ou de algo não imagético; não se trata de pensar por representação e evocação do objeto ou do mundo material. $\mathrm{Na}$ experiência literária pensada por Blanchot, essas imagens imaginárias inventam-se na superfície da própria escritura, e podem chegar a um ponto em que a questão não mais gira em torno da realidade ou irrealidade do imaginário. “[...] imagem, imaginário e imaginação não designam apenas a aptidão para os fantasmas interiores, mas também o acesso à realidade própria do irreal [...] e ao mesmo tempo a medida recriadora e renovadora do real que é a abertura da irrealidade" 27 .

A imagem imaginária que percorre a experiência da literatura se engendra a partir da presença de uma ausência, ou da ausência como presença, como nos diz Blanchot, no fascínio que arrasta o pensamento para uma regiáo fora de si. Nesse sentido, o fascínio que nos arrasta para a imagem seria uma paixão do fora, que nos tira de nós mesmos por meio de potências estranhas, que atraem para turbulentas regióes de obscuridade, dilacerando a noção de interioridade reflexiva. A imagem aparece como aquilo que cavalga intensa e teimosamente uma ausência, com a voragem de uma presença, e que, imantada, arrasta aquele que olha, que imagina.

[...] a essência da imagem é estar toda para fora, sem intimidade, e no entanto mais inacessível e misteriosa do que o pensamento do foro interior; sem significação, mas chamando a profundidade de todo sentido possível; irrevelada e, no entanto, manifesta, como a presença-ausência que constitui o atrativo e o fascínio das Sereias. ${ }^{28}$

O estranho caso de Angélica começa pela noite, quando um homem procura um fotógrafo para tirar fotos de uma jovem mulher falecida. Ao sair do quarto de pensão no início do filme, Isaac é atraído pela noite que se avoluma no caminho para o velório. A imagem de Angélica, que retorna incessantemente a Isaac, mantém uma relação intensa com a noite, com a escuridáo desconhecida que banha o filme em muitos instantes. Nesse ponto, a concepçáo de outra noite pensada por Blanchot é fundamental para pensarmos a insistente presença da noite no filme, que envolve as aparições da imagem de Angélica. Para 
Blanchot $^{29}$, a primeira noite é aquela em que o repouso e o sono acolhem, noite em que se pode entrar depois do dia e encontrar o descanso, assim como a morte definitiva, terminada. Trata-se de uma noite que conforta. Entretanto, Blanchot fala da outra noite, que não oferece uma acolhida como a primeira; na outra noite estamos sempre do lado de fora, diante de um vazio em que o desaparecimento aparece, cujo fundo inacessível da noite torna-se presente naquilo que sumiu.

[...] quando tudo desapareceu na noite, "tudo desapareceu" aparece. É a outra noite. A noite é o aparecimento de "tudo desapareceu". É o que se pressente quando os sonhos substituem o sono, quando os mortos passam ao fundo da noite, quando o fundo da noite aparece naqueles que desapareceram. As apariçôes, os fantasmas e os sonhos são uma alusão a essa noite vazia [...] O que aparece na noite é a noite que aparece, e a estranheza não provém somente de algo invisível que se faria ver ao abrigo e a pedido das trevas: o invisível é então o que não se pode deixar de ver, o incessante que se faz ver. ${ }^{30}$

A experiência do fascínio que arrebata o fotógrafo acontece na noite, liga-se ao invisível inexorável que aparece na escuridão. Isaac não consegue deixar de olhar para essa aparição do invisível que o transtorna; ele se fascina pela imagem de Angélica que carrega inúmeras outras imagens, e que não deixa de guardar traços da antiga Ninfa pagã que pode retornar transfigurada em imagem de anjo feminino. No limite, o fotógrafo fascina-se pela própria noite que o mantém sempre do lado de fora, pela aparição daquilo que desapareceu. No filme, o rosto de Angélica se transformou em uma imagem aterrorizante e sutil. Isaac fascinou-se pelas potências dessa imagem fabricada no instante em que a câmera capta os traços de luz e sombra do rosto mórbido. Essa imagem desassossegada escapa ao aniquilamento absoluto, e torna presente a ausência daquilo que feneceu nas curvas do tempo. Na imagem inquietante de Angélica, Isaac encontra uma espécie de canto de sereia que o atrai incessantemente para uma região desconhecida. Sob o estranho efeito do fascínio, o fotógrafo corre desembestado pela pequena cidade até a exaustão, e se entrega a um cansaço que vai envolvendo-o cada vez mais até o limite do corpo, quando cai no meio de um descampado. Diante do rosto pálido de Angélica, o fotógrafo encontrou a assustadora e atraente abertura vertiginosa do fora, regiáo imaginária que beira a morte e que faz nascer o fascínio da imagem que perturba o presente.
29. BLANCHOT, O espaço

literário, 2011.

30. Ibidem, p. 177. 


\section{Referências}

AGAMBEN, Giorgio. Ninfas. Tradução de Renato Ambrósio. São Paulo: Hedra, 2012.

BEGHIN, Cyril. Manoel de Oliveira: L'étrange affaire Angélica. Paris: Centre national du cinéma et de l'image animée, 2013.

BLANCHOT, Maurice. A conversa infinita I: a palavra plural. Tradução de Aurélio Guerra Neto. São Paulo: Escuta, 2010a. - A conversa infinita II: a experiência limite. Traduçáo de João Moura Jr. São Paulo: Escuta. 2007.

- A conversa infinita III: a ausência de livro, o neutro, o fragmentário. Tradução de João Moura Jr. São Paulo: Escuta, 2010b.

. O espaço literário. Tradução de Álvaro Cabral. Rio de Janeiro: Rocco, 2011.

O livro por vir. Tradução de Leyla Perrone-Moisés. São Paulo: Martins Fontes, 2005.

DIDI-HUBERMAN, Georges. A imagem sobrevivente: história da arte e tempo dos fantasmas segundo Aby Warburg. Tradução de Vera Ribeiro. Rio de Janeiro: Contraponto, 2013.

"De semelhança a semelhança". Alea. v.13, n. 1, p. 2651, jan./jun. 2011.

FOUCAULT, Michel. "O pensamento do exterior". In:

Ditos e Escritos III - Estética: Literatura e Pintura, Música e Cinema. Tradução de Inês Autran Dourado Barbosa. 2. ed. Rio de Janeiro: Forense Universitária, 2009.

. "Sobre as maneiras de escrever a história". In:

Ditos e Escritos II - Arqueologia das ciências e história dos sistemas de pensamento. Tradução de Elisa Monteiro. 2. ed. Rio de Janeiro: Forense Universitária, 2008.

OLIVEIRA, Manoel de. Angélica (1954): un découpage. Paris: Editions Dis-Voir, 1993.

"Esta minha paixão". In: . Manoel de Oliveira.

MACHADO, Alvaro (org.). São Paulo: Cosac Naify, 2005

La Métaphysique des anges: entretien avec Antonio Preto.

Paris: Dossier de presse - Épicentre Films, 2010.

RÉGIO, José. "Sarça Ardente, parte 16". In: As encruzilhadas de Deus. 6a ed. Porto: Brasília Editora, 1970. 
WARBURG, Aby (1912). "A arte Italiana e a astrologia internacional no Palazzo Schifanoia, em Ferrara”. In: A renovação da Antiguidade pagã: contribuiçóes cientificoculturais para a história do Renascimento europeu. Tradução de Markus Hediger. Rio de Janeiro: Contraponto, 2013c.

(1914). "A emergência do estilo ideal à antiga na pintura do início do Renascimento". In: A renovação da Antiguidade pagã: contribuiçôes científico-culturais para a história do Renascimento europeu. Tradução de Markus Hediger. Rio de Janeiro: Contraponto, 2013b.

(1905) “Dürer e a Antiguidade Italiana”. In: . A renovação da Antiguidade pagã: contribuiçôes científico-culturais para a história do Renascimento europeu. Tradução de Markus Hediger. Rio de Janeiro: Contraponto, 2013a.

(1893). "O nascimento da Venus e A Primavera de Sandro Botticelli”. In: - A renovação da Antiguidade pagã: contribuiçôes científico-culturais para a história do Renascimento europeu. Tradução de Markus Hediger. Rio de Janeiro: Contraponto, 2013d.

. (1898). "Sandro Botticelli". In: A renovação da Antiguidade pagãa: contribuiçôes científico-culturais para a história do Renascimento europeu. Tradução de Markus Hediger. Rio de Janeiro: Contraponto, 2013e.

\section{Filme}

O ESTRANHO CASO DE ANGÉLICA. Diretor Manoel de Oliveira. Portugal, Brasil, França: 2010. 1 Dvd (97 min.), cor. 
